\title{
Behavioral Patterns of Women Who Employ Their Leisure Time in Sports Activities: An Application of the Football Branch
}

\author{
Yeşer Eroğlu ${ }^{1}$, Selami Özsoy ${ }^{2}$ \\ ${ }^{1}$ İstanbul Gedik University, Faculty of Sport Sciences, Department of Sport Management, İstanbul, Turkey \\ ${ }^{2}$ AbantİzzetBaysalUniversity, Faculty of Communication, Department of Journalism, Bolu, Turkey \\ Correspondence: Yeşer Eroğlu, İstanbul Gedik University Faculty of Sport Sciences, Cumhuriyet Mahallesi İlkbahar \\ Sokak No: 1-3-5, Yakacık, 34876, Kartal, İstanbul, Turkey.
}

Received: August 1, 2017

doi:10.11114/jets.v5i10.2570
Online Published: September 8, 2017

URL: https://doi.org/10.11114/jets.v5i10.2570

\begin{abstract}
This study is conducted to reveal the role of gender in attending leisure time activities and to determine gender perceptions about sports branches. For this purpose, an application was performed with the participation of 7 female students from Abant Izzet Baysal University School of Physical Education and Sport. For 8 weeks, volunteer participants saw home-field football matches of Boluspor Football Team, playing in the First League of Turkish Football Federation. Focus group discussions were conducted with the participants both before and after the application. The research was based on qualitative method, and the data of the research was analyzed via NVIVO 10 program. It is detected that the participants had negative perceptions about attending a football match before the application, but this transformed into a positive perception after the application. Participants emphasized that there were some obstacles in front of women in attending leisure time activities, yet argued that these obstacles could disappear with increased participation. Participants also remarked that negative perception shared by the people in their close circles about seeing football matches transformed into positive perception after the application. Moreover, participants stated that attending leisure time activities strengthened socialization and communication.
\end{abstract}

Keywords: recreation, gender, football

\section{Introduction}

Time is the most important phenomenon in our lives; we use time to plan our actions and make plans or to adapt ourselves to those plans (Özbey \& Çelebi, 2011). Time is a phenomenon and a validity having physical, philosophical, and sociological aspects, and incomprehensible by sense organs, it is also a limited, invaluable and scarce source for humanity. As people consume time, time also consumes people (Munusturlar, 2016).

Turkish Language Society defines "recreation" (in Turkish rekreasyon, a word of French origin) as "leisure time activities of voluntary participation with the purpose of entertainment and sport" (tdk.gov.tr). Recreationwas derived from the Latin word "recreatio" that means "revival, renewal". Turkish word rekreasyon is widely used in the meaning of making use of one's spare time. This definition shows that recreation has a direct and close relation to leisure time, because it is primarily related to the activities that can be performed by people who have spare time. Spare time defines the period outside working hours (Karaküçük, 1997).

Recreation is used to define different leisure time activities such as entertainment, art, cultural activities as well as dancing, hunting, fishing, etc. within the field of physical education and sport. There are three important functions of leisure time: relaxation, entertainment, and improving oneself. Intellect and abilities that are improved during leisure time activities are not only essential for individuals but also for the society that these individuals belong to. Therefore societies are closely related to "recreational activities" performed during leisure time (Zorba, 2007).

Leisure is voluntary behavior. Expressed at the most prosaic level, Leisure studies is the analysis of voluntary behavior. Choice, freedom and voluntarism are the basic components in the narration of leisure (Rojek, 2005).

The terms leisure and recreation relate to the period of spare time in which individuals are exempted from work and duties and are able to engage in activities of their choice not imposed by necessity. Recreational and leisure activities depend on individual interests and personal definition of relaxation, diversion, entertainment and pleasure. Both terms 
encompass a very diverse and broad field of activities including sports, food and dining, various arts and crafts, media entertainment, gaming, literature, festivals and fairs, shopping, social clubs, family activities and vacations as well as volunteering and hobbies (Koshar, 2002).

The function of liberation is especially important for recreation. Individuals are enslaved by time due to obligations and commitments, and can master over time in the absence of these obligations and commitments; thus one can obtain the opportunity of recognizing one's potential, revealing one's hidden energy and using this energy creatively, in short, achieving self-fulfillment. Self-fulfillment is the fundamental utilization form of spare time that is constructed by recreation. The need for self-fulfillment is synonymous to recreational purposes because it expresses the need of actualizing one's whole potential and living the life to the fullest. While satisfying the need of actualizing oneself, people also obtain the chance to satisfy the need of relaxation and entertainment through some of the activities within the scope of recreation (Demirci Orel \&Yavuz, 2003).

Considering woman's place in society, her need for recreational activities and self-fulfillment cannot be denied. One of the essential tools in the process of relaxation is active or passive participation in sport. Women and sport in the modernization process is considered as a special issue within social transformation problematic. Socialization of women through sport can be considered as a parameter within the process of modernity.

Sports activities are performed for different and most of the time contradicting purposes. These purposes range from maintaining a healthy life to being strong, from socializing to earning money (Amman, 2006).

According to gender perception, sport is considered to be a male activity and superior sportive performance is identified with manhood. Most of the sports branches are male-dominated, and women have a limited place in common sports branches. This domination can be seen not only among sportsmen/women but also in audience and the people who transfer sports activities to the audience through mass media.

The lower level of interest of women towards active participation in sports is directly related to the condition of being the receiver instead of participator. The reasons of this difference are; first, wide-range representation of dominant sports branches in journalism, and second, sexist socialization at schools and home. Female discourse indicates that woman's derivativeness is accepted (Özsoy, 2016).

There is a great inequality between men and women in terms of attending sport. There is a need to eliminate the otherization of women in sports fields and to increase their participation in sports programs.

Women are not considered enough in sport politics that aims to popularize sport in society. It is necessary to integrate gender aspect into public activities, which are actualized in order to improve sport, and into the funds transferred to these activities. In the process of improving sport, it should be considered as a requirement of modernity to curtail the otherization of women and to increase their participation in sports programs.

This study aims to reveal the transformation of perception upon the participation of women in football, which is considered as a male-dominated sports field, where men are commonly represented.

\section{Method}

\subsection{Research Model}

This is an activity research conducted by applying qualitative methods. The purpose of using action research with qualitative methods is the flexible structure and the lack of generalization goal in qualitative research.(Mills, 2000; qtd in: Yıldırım \& Şimşek, 2013).This is planned as an activity research with the aim of leading female students to attend football matches as audience as a leisure time activity.

\subsection{Participants}

This study was conducted with the voluntary participation of 7 female students who were students at Abant Izzet Baysal University School of Physical Education and Sport. Participant students were selected in accordance with the nature of qualitative research by using convenience sampling, which is one of the purposeful sampling methods. Convenience sampling earns the researcher speed and practicability. 
Table 1. Profiles of research participants

\begin{tabular}{lllll}
\hline & & Participant Features & \\
\hline Participant & Age & Branch & Sport age & Student's Department \\
G & 20 & Volleyball & 7 & Physical Education Teacher \\
V & 20 & Kung fu & 6 & Physical Education Teacher \\
S & 21 & Volleyball & 5 & Physical Education Teacher \\
M & 21 & Swimming & 5 & Trainer Education \\
C & 22 & Swimming & 8 & Physical Education Teacher \\
K & 20 & Badminton & 4 & Trainer Education \\
B & 20 & Badminton & 4 & Physical Education Teacher \\
\hline
\end{tabular}

\subsection{Data Gathering}

Focus group is a special group discussion technique, which is structured in order to define detailed information and views of the selected participant group within a specific subject. Discussion is moderated by a specialist who uses question and condensation techniques with the purpose of revealing people's thoughts and lives (Merriam, 2015). According to Bowling (2002) focus group discussion is using the influence of group dynamic, acquiring in-depth information, and producing ideas during meetings and discussions that are not held between a small group and a leader. The purpose of focus group discussions is to acquire in-depth, detailed and multi-dimensional qualitative information about participants' points of view, lives, interests, experiences, tendencies, thoughts, perceptions, emotions, attitudes and habits about a specific subject (Çokluk, Yılmaz, \&Oğuz, 2011).

\subsection{Action (Application) Plan}

This study took a period of 16 weeks that covered 8 matches of Boluspor (a First League Club within Turkish Football Federation) in the home field during the 2016-2017 Football Season. Two students (project coordinators), who were trained for this project, accompanied the participants throughout the process. Before the action, the researchers prepared their plans about the football matches and informed the participants.

Both before and after the application, face-to-face focus group discussions were held with the participant students. Details related to the application phase subsequent to pre-action phase are given in Table 1. Project coordinator students went to see the football matches with the participants throughout the application. After the applications, researchers held focus group discussions with the participants again, and data related to applications was revealed.

Table 2. Football matches and dates that the participants saw in the scope of this application.

\begin{tabular}{lll}
\hline Matches & Date & Project Coordinator Student \\
\hline Boluspor - Balıkesirspor & $04-12-2017$ & Ceren Pekyapalak - Merve Kuzu \\
Boluspor - YeniMalatyaspor & $24-12-2017$ & Ceren Pekyapalak - Merve Kuzu \\
Boluspor - Elazığspor & $29-01-2017$ & Ceren Pekyapalak - Merve Kuzu \\
Boluspor - Ümraniyespor & $19-02-2017$ & Ceren Pekyapalak - Merve Kuzu \\
Boluspor - Eskişehirspor & $04-03-2017$ & Ceren Pekyapalak - Merve Kuzu \\
Boluspor - Giresunspor & $18-03-2017$ & Ceren Pekyapalak - Merve Kuzu \\
Boluspor - Göztepe & $07-04-2017$ & Ceren Pekyapalak - Merve Kuzu \\
Boluspor - Bandırmaspor & $23-04-2017$ & Ceren Pekyapalak - Merve Kuzu \\
\hline
\end{tabular}

\subsection{Data Analysis}

Descriptive analysis and content analysis were used in the research. Data obtained in descriptive analysis by using sound recorder was processed and transferred into electronic environment by the researchers who specialized in qualitative research. Moreover, consistency between researcher's short notes and findings was inspected. Data obtained through focus group discussions was textualized in computer environment, and this data is transferred to NVIVO 10 program during the content analysis.

The coding in the process of data analysis was generated by two sets of independent units: first, researchers, and second, a scholar who was an experienced specialist in the field of qualitative research. The statements that overlapped in coding were classified under specific themes.

\subsection{Validity and Credibility}

To ensure the consistency of the research, the researchers and field specialist scholar generated data together, and themes were constituted. "Consensus" and "Dissensus" were used for the codes and themes determined by the researchers and field specialist. Miles and Huberman's (1994) credibility formula Reconciliation Percentage \% $=[\mathrm{Na}$ (Consensus) $/ \mathrm{Na}$ (Consensus) + Nd (Dissensus)] X 100 was used for the research's credibility calculation. 
Specified statements are: consensus 85 code and dissensus 12 code. In accordance with this formula, the credibility rate of this study is $87 \%$. According to Miles and Huberman (1994) a credibility rate of over $70 \%$ is sufficient.

\section{Results}

Findings obtained in the research are gathered in two groups: pre-application and post-application.

\subsection{Pre-Application}

According to the analysis of focus group discussion that was held before the application, participant women's approaches to using leisure time in sports environment are gathered under and summarized in 7 themes.

1. Idea of leisure time (spare time, time we spared for ourselves, getting out of routine, motivating activity, cheerful activity)

2. Leisure time activities (watching television series, seeing sports matches, waiting tables, seeing football, spending time with friends)

3. Hobbies (listening to music, traveling, doing exercise, playing football, seeing sports matches)

4. Thoughts about football (a popular sports branch, high financial income, male-dominated branch)

5. Thoughts about women and football (women should sit on tribunes, prejudice, negative cheering, minority, family pressure, violence, fear)

6. Partisanship (seeing the matches of every team, promotion and relegation matches, competitive matches, successful team matches)

7. Reasons to see matches (ambiance, pleasure, entertainment)

Participants used the statements such as "power", "happiness", "adrenalin", "curiosity", "sacrifice" and "commitment" to define the perception created by the word "football".

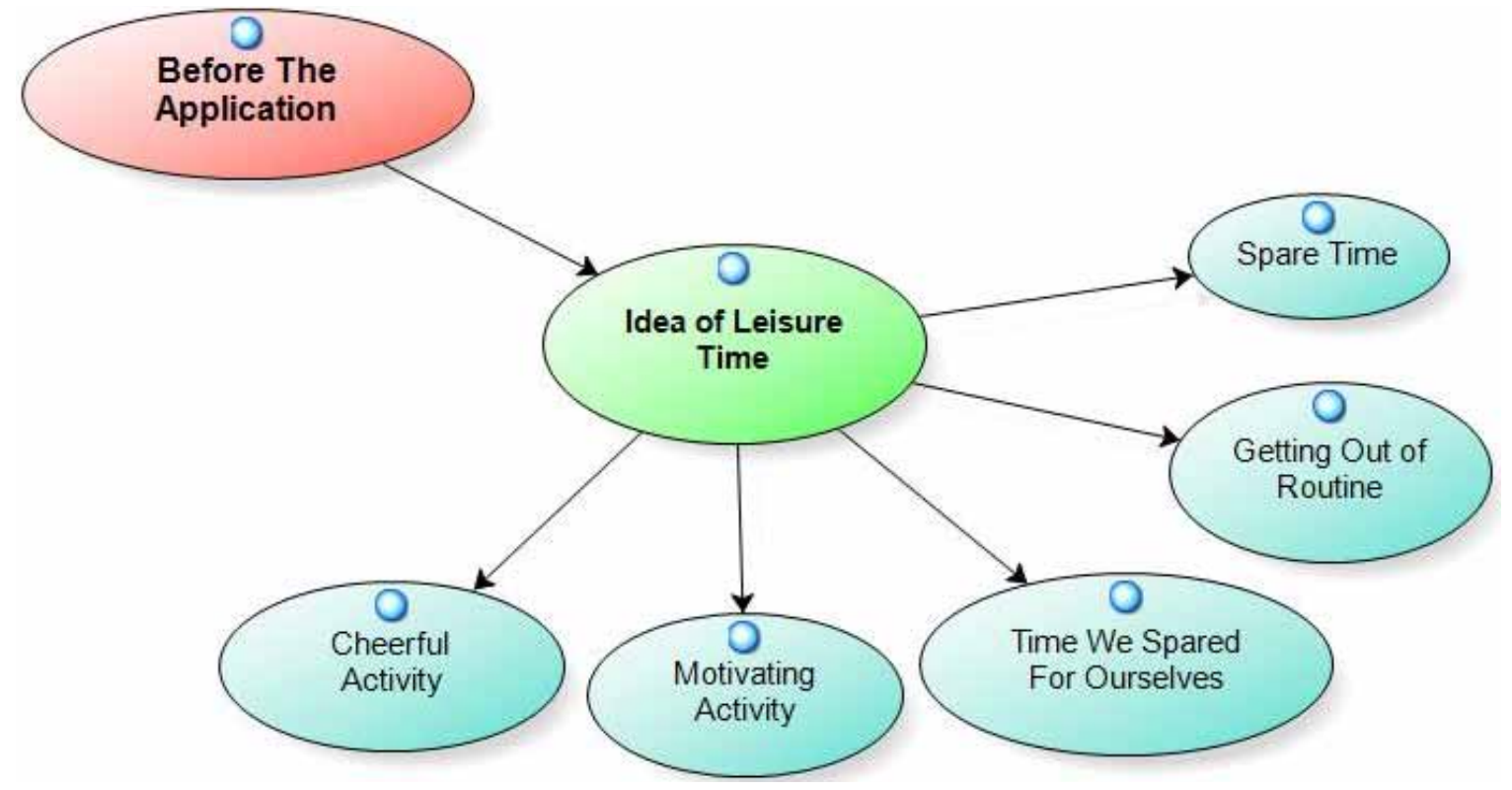

Participants' thoughts about "leisure time" before the application were stated as; "cheerful activity", "motivating activity", "time we spared for ourselves", "getting out of routine" and "spare time". Participant S said, "It is a period of time which covers activities that we do to motivate or please ourselves and that are out of our routine activities." Participant K said, "We can think it as a period of time we spare for ourselves". 


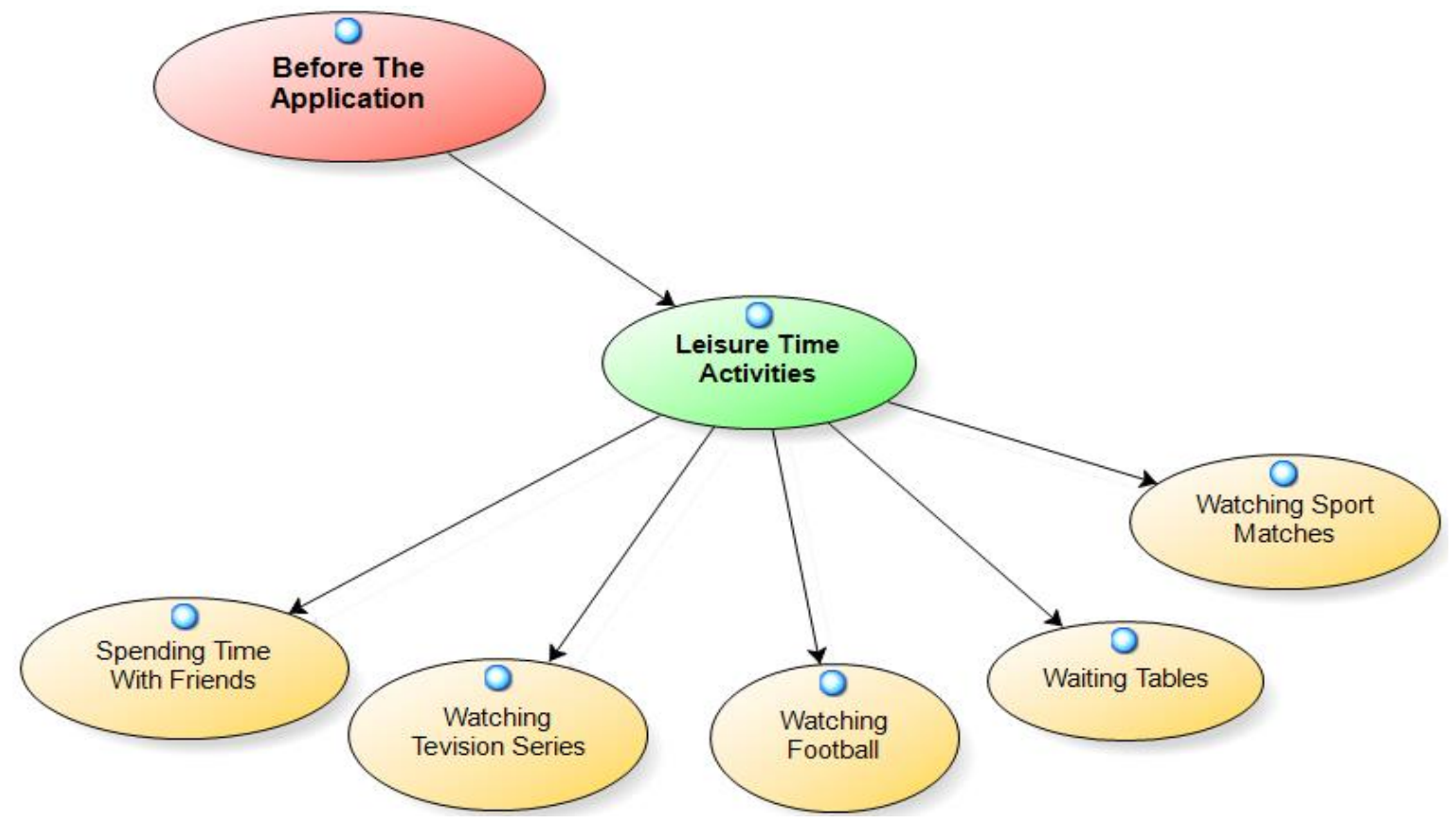

Participants defined their leisure time activities before the application as sports related activities that include active and passive participation. Participants' approaches to this issue are: "Especially football, either live, online, on TV or in the stadium. Ziraat Turkish Cup, TFF First League, I watch everything" (Participant M). "I do exercise, and I also do stuff with my friends, I spend time with them" (Participant K). "I don't watch TV, except the football matches aired on TRT. Before I didn't watch TV at all, but now I only watch TV for football matches" (Participant K) "I play with my little brother/sister, she/he is also interested in playing ball, I also like to travel, I usually travel” (Participant G).

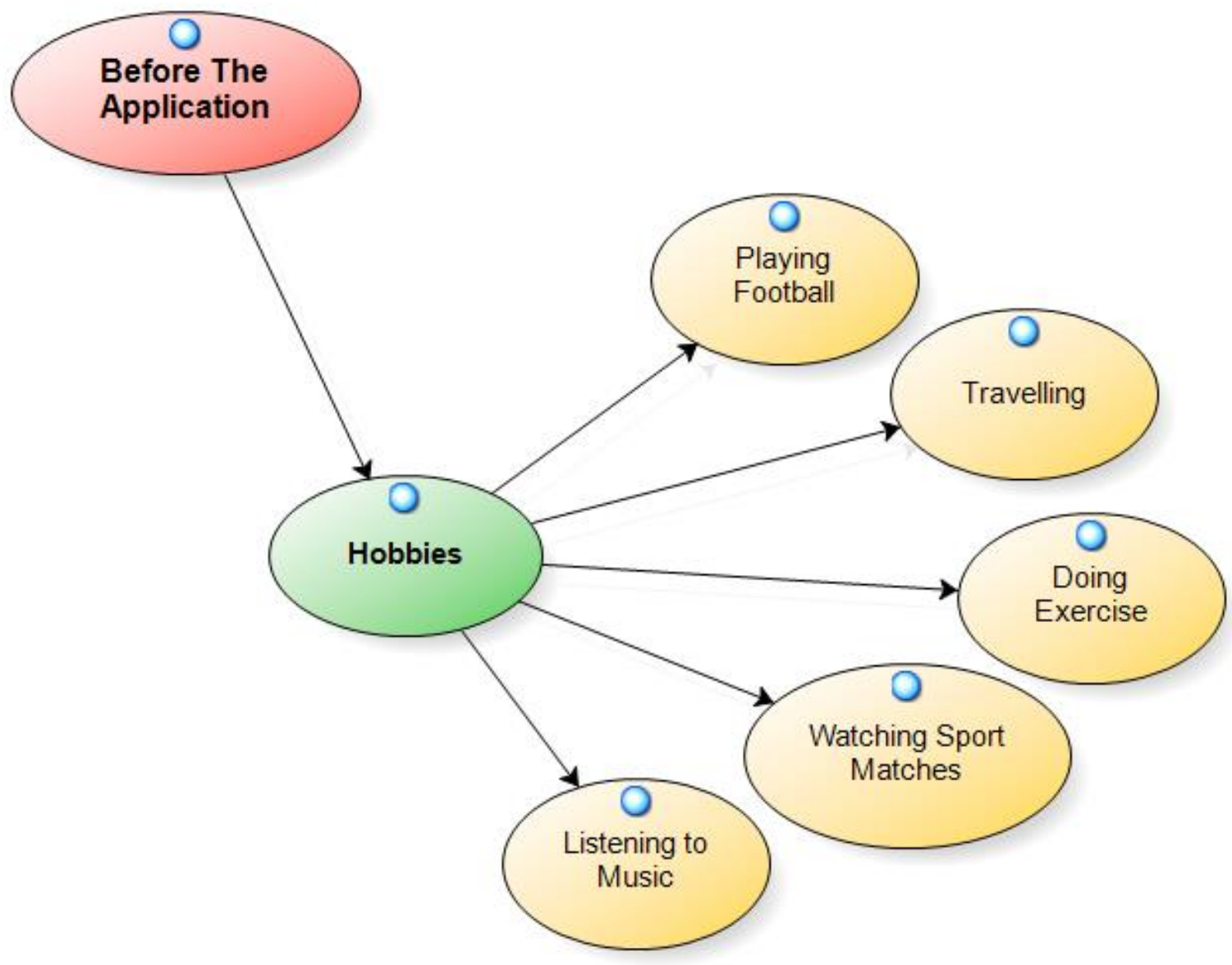


Participants talked about their hobbies before the application. These hobbies are classified under the headings such as playing football, travelling, watching all kinds of matches, and listening to music. Two participants stated that they had sports related hobbies. By emphasizing her interest in football, Participant M said, "I like both playing and watching, both are pleasing." Participant B said, "I try to listen to different kinds of music, I try to change my style." While talking about her hobbies, Participant C said, "I have a license for being a football referee but I don't like being a football referee. Instead, I like sitting on tribune and comment on players. I say things like 'this one plays really good, this one is better at one-to-one, this one is better at long-distance shots, this one's right foot is better and has strong ankles.' I like comparing physical superiorities of the players."

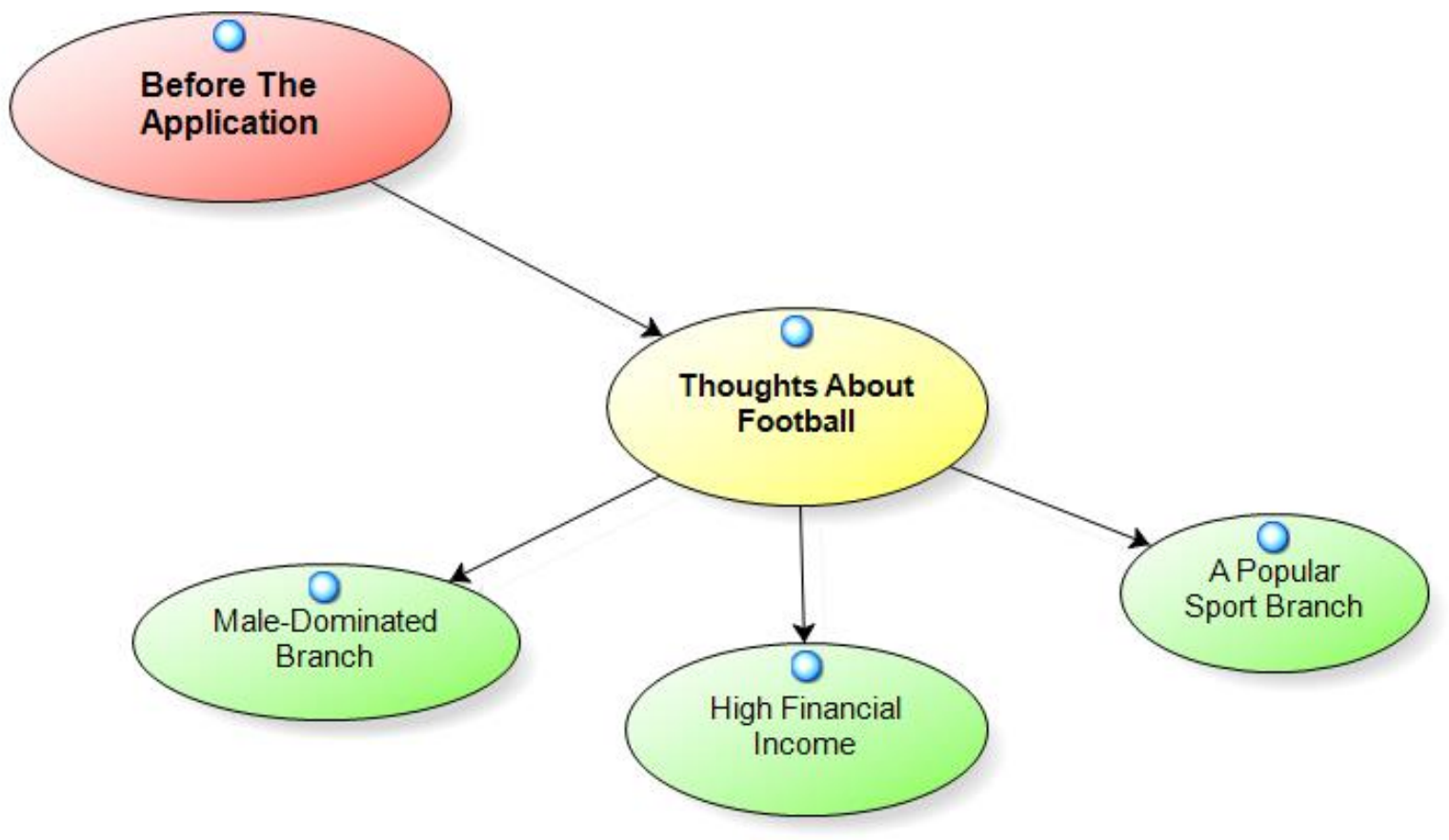

Before the application the participants explained their thoughts about football by putting emphasis on income, extensiveness, and manhood. Participant S said, "Football is on the spotlight everywhere, the most valuable sports branch." Participant K said, "I think football is seen with its financial aspects, not as a sports branch, for example a father thinks his child will earn money in the future when he is registering his child to a football course." 


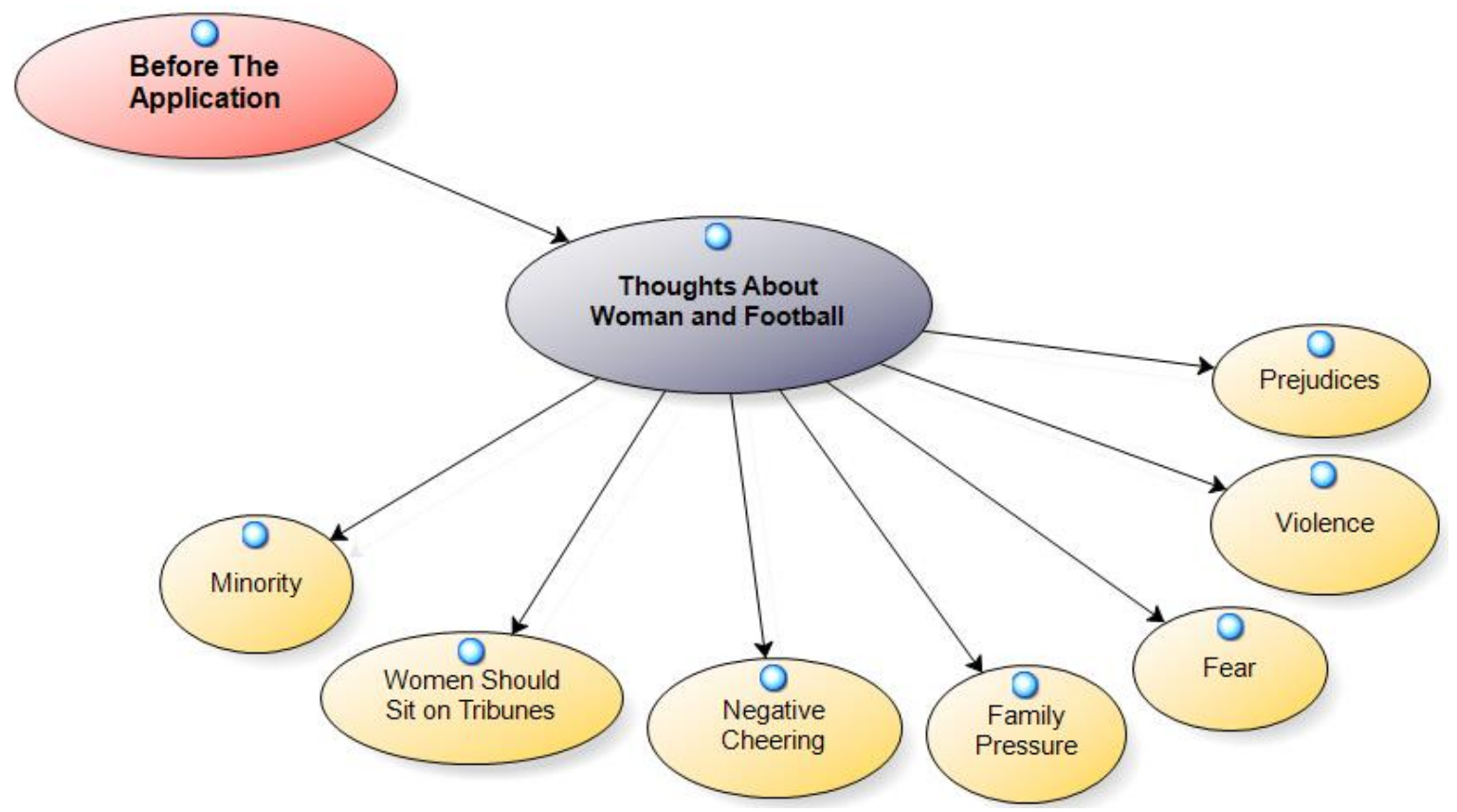

While explaining their views about "Football and Woman" relationship before the application, participants emphasized the scarcity of female audience and drew attention to several negations in sports such as fear, violence, and unfavorable cheering. About the scarcity of women sitting on tribune, Participant M said, "Women are so few in number that it is not possible to notice their presence." While explaining that it was necessary to have more women on tribune, Participant B said, "I think everyone should take place on tribunes equally. The prejudices against the presence of women in football matches should disappear." Drawing attention to Boluspor's practice during 2007-2008 season, Participant C said "It was Boluspor which opened the first women and children tribune. Unfortunately that tribune was closed because of Passolig." While explaining the reasons related to the scarcity of women on tribunes, Participant B put an emphasis on family pressure and said, "There is this idea that a fight could break out any moment. My family puts pressure the same way, they want me to stay away saying that it is not my business."

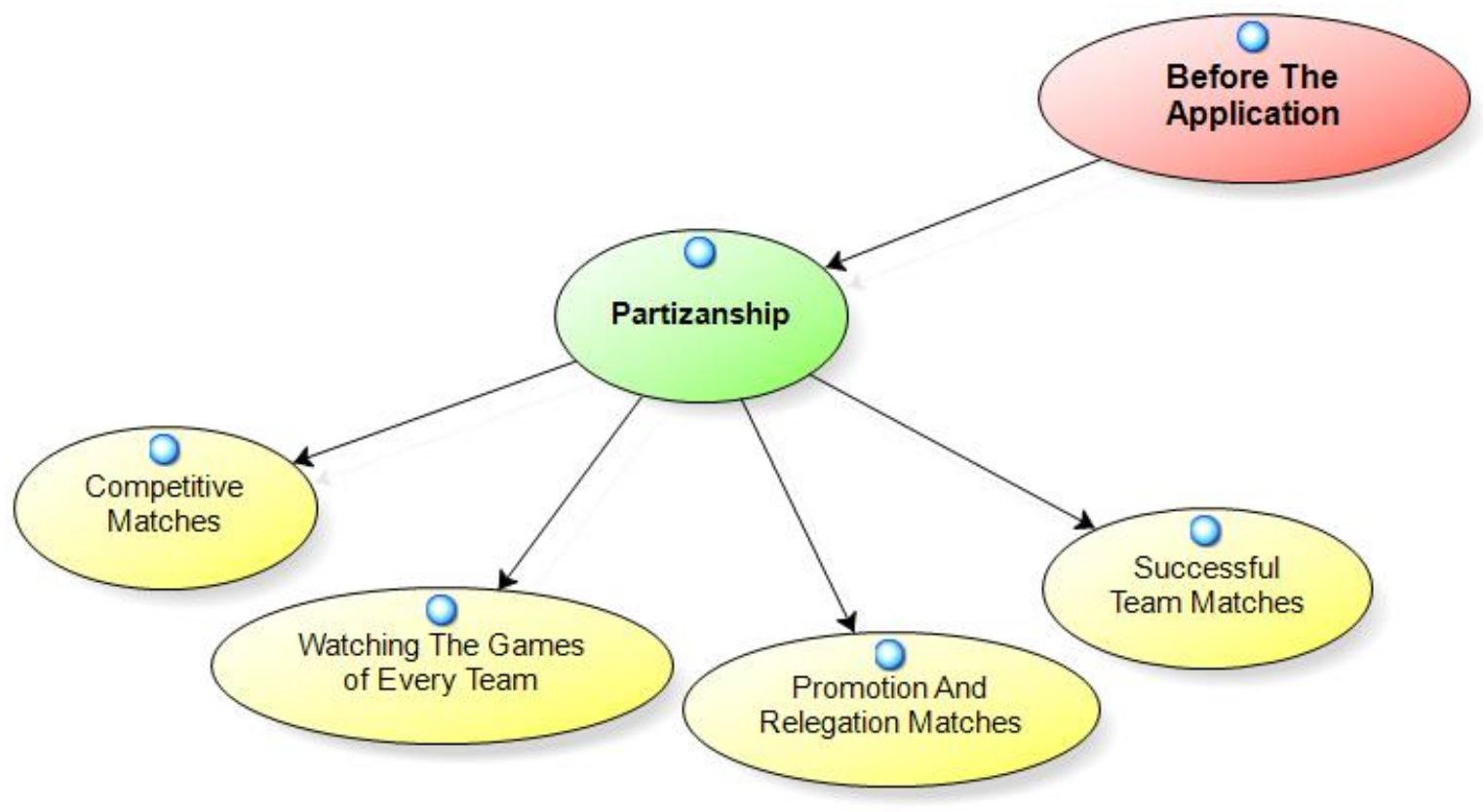

Participants stated their views on the matches they had seen before the application and these views are gathered under 4 themes that include concepts such as "competition, success, pleasure and excitement." Participant M and Participant S explained why the competitive matches drew more attention as: "I think when the competition is stronger between the 
rival teams, it gives more pleasure. Adrenalin, actually you take pleasure, when conflict is higher" (Participant M). "If the competition is good, fierce, and if I take pleasure in it, I see the matches of not only the club I am supporting but also the others (Participant S). Participant B said, "It gives more pleasure to see the matches of the club you support." Participant $\mathrm{C}$ explained which matches she liked as "Especially through the end of the season, if your team is among the first six teams in championship matches, it has a chance to promote to Super League, those matches are very exciting; or the relegation matches are more cheerful."

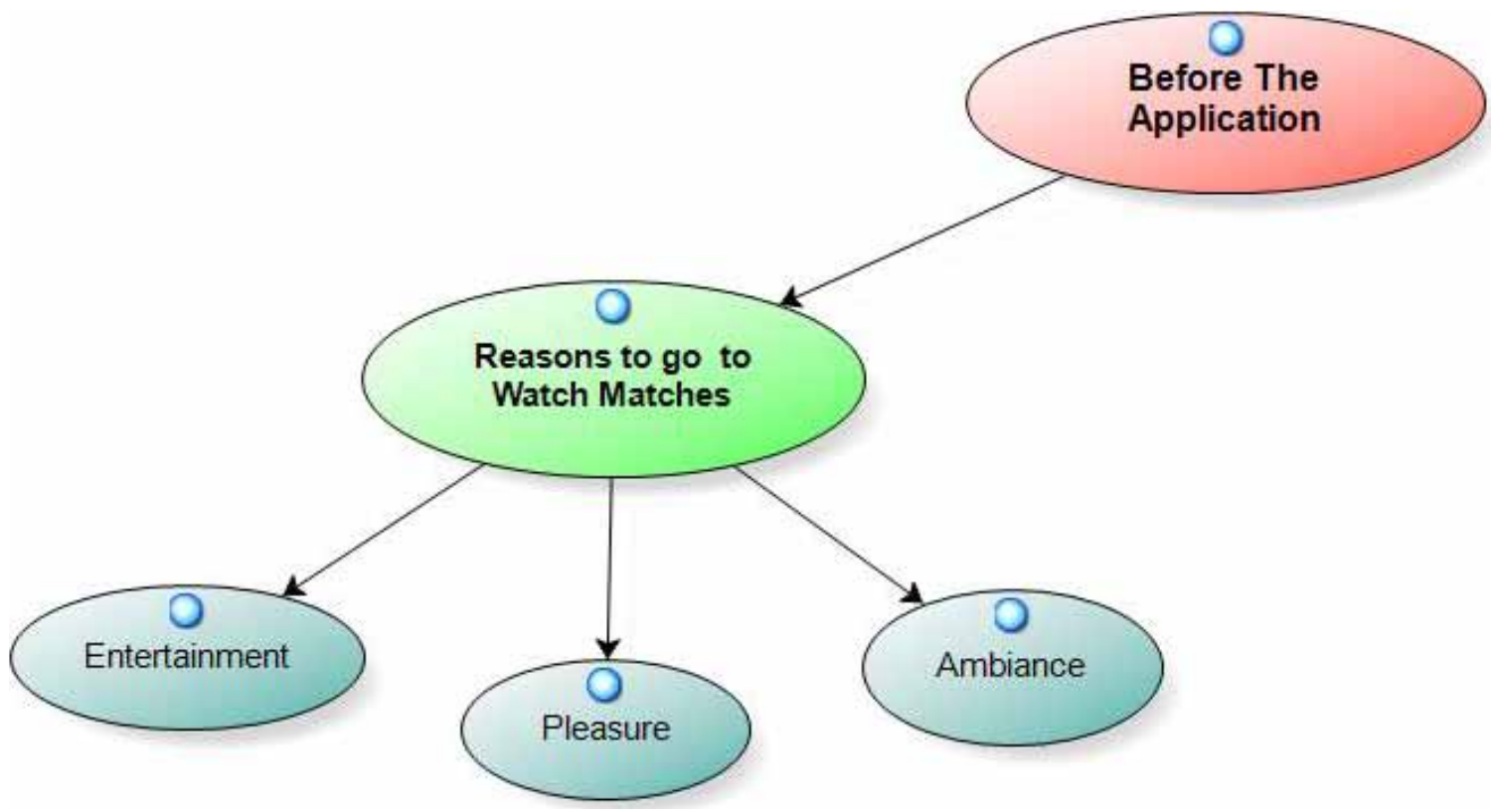

Before the application, participants explained why they went to see matches and their views are classified as "entertainment", "pleasure" and "ambiance". Participant K stated that she went to matches because she wanted the club she supported to win, and said, "I like the ambiance of tribune very much." Participant V said, "It is about having a pleasing and entertaining time for me." Participant $\mathrm{M}$ also emphasized taking pleasure and stated her views as: "I don't think winning is everything, what is more important is taking pleasure. Because why would you go on a cold day, instead of watching it on TV! Why would I go there if I didn't take pleasure!"

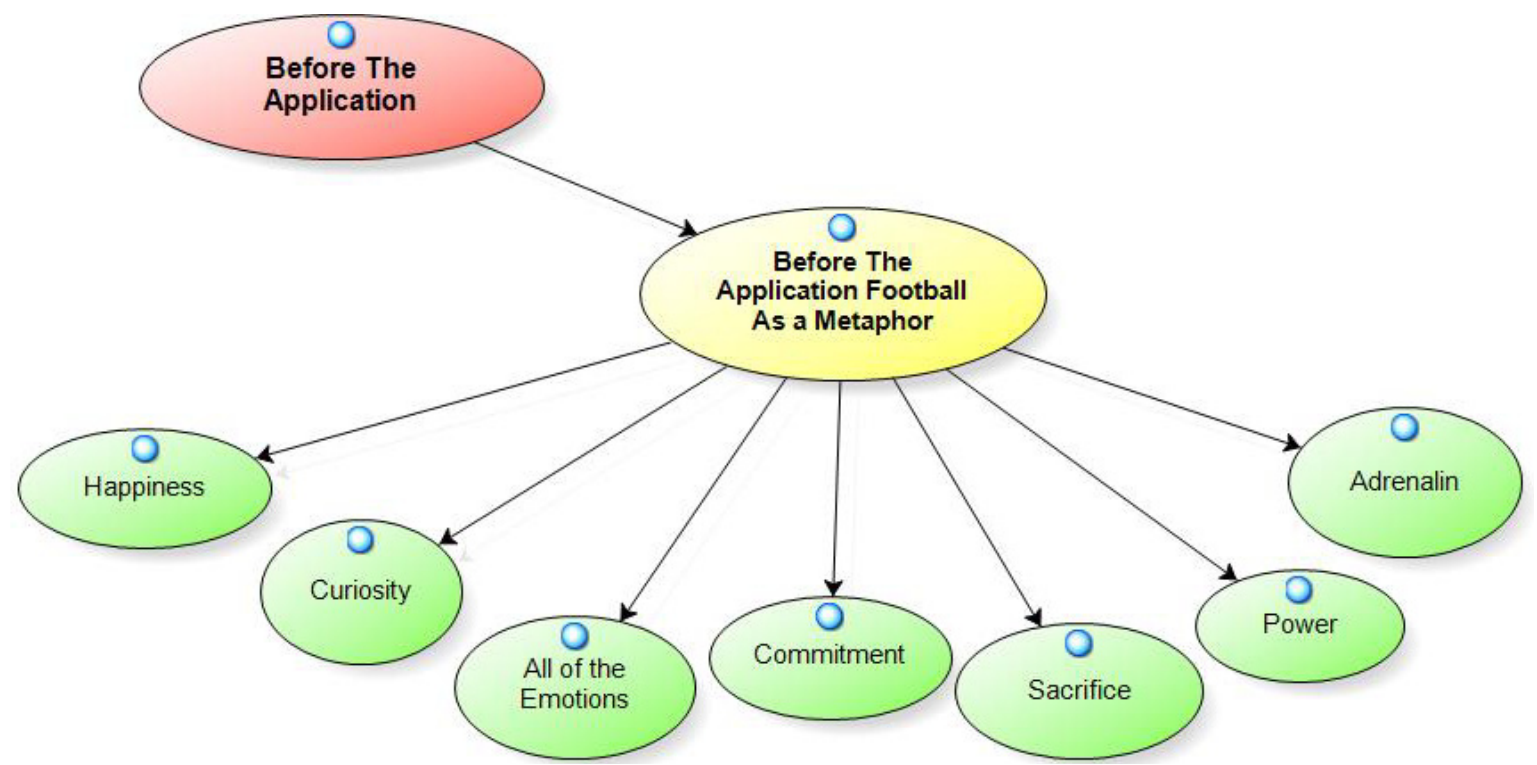

Before the application, participants were asked to think football as a metaphor, their answers are as given: Football: Power (Participant M), Football: Happiness (Participant C), Football: Adrenalin (Participant B), Football: Curiosity (Participant S), Football: Sacrifice (Participant G), Football: Commitment (Participant V), Football: All of the emotions (Participant K). 


\subsection{Post-Application}

Participants' views after the application are grouped under 5 themes following the analysis: Being in a male-dominant space(getting used to the environment, getting used to the presence of women, acceptance, sense of belonging, common goal), reaction of the people (family pressure, respect, finding it interesting, social pressure), the change that came with football (happiness, getting rid of stress, awareness, desire to follow the field, entertainment, thrill, embracing), end of the activity (desire for, understanding men, acceptance, dreaming), differences between genders (equality, fear from the environment, self-confidence, necessity for women, acceptance, normalcy, communication, integrity, tranquility).

While defining the meaning of football after the application, participants used the statements as water, commitment, sociability, all the emotions including the good and the bad ones, happiness and tranquility, communication.

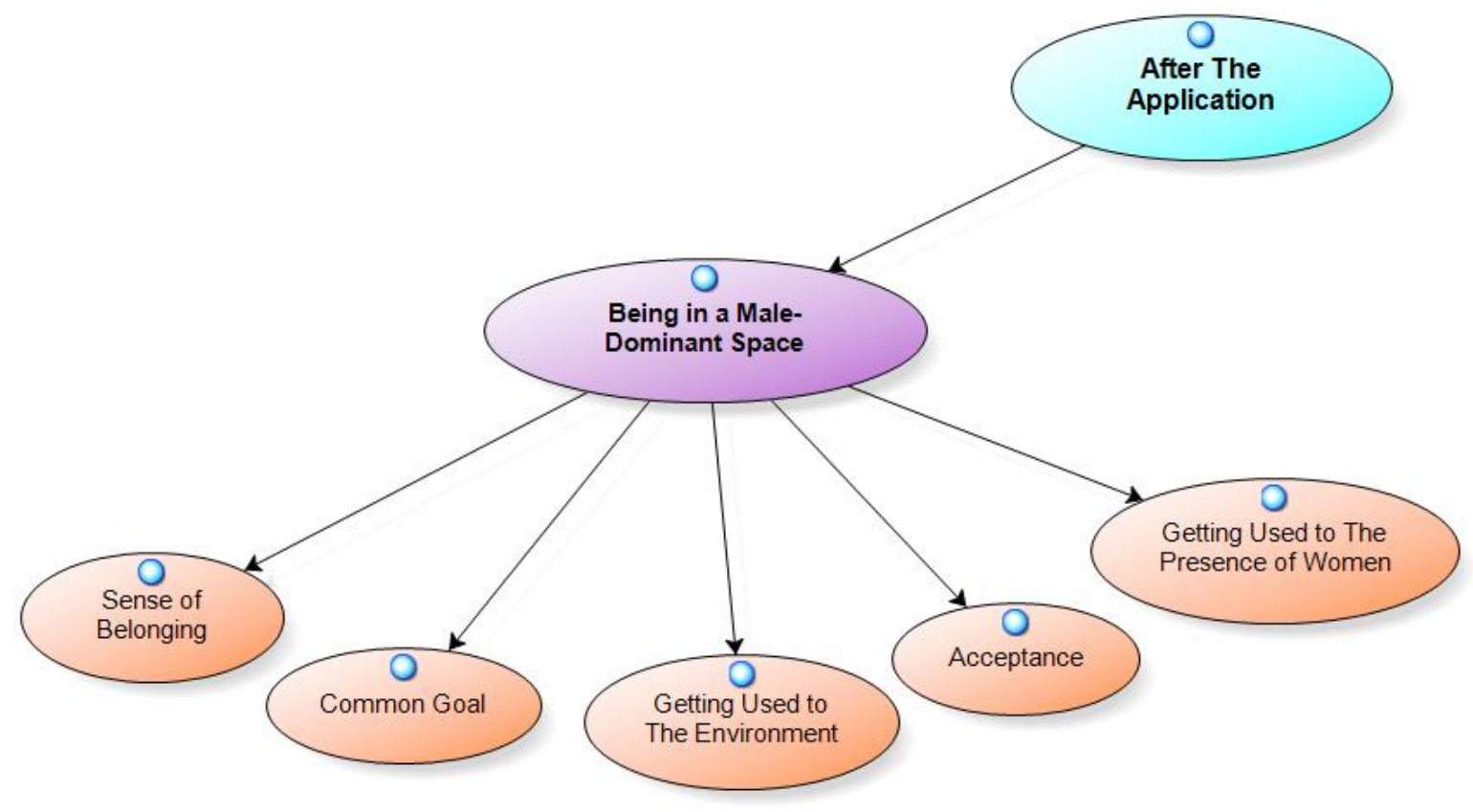

"Being in a male-dominated space" theme is obtained through the analysis of participant views after the application; this theme is construed through the sub-themes of "sense of belonging", "common goal", "acceptance" and "getting used to the presence of women".

While expressing their post-application experiences, Participant $\mathrm{K}$ and Participant $\mathrm{C}$ used the concept of getting used to the environment. Participant $C$ said, "You get used to the environment and when you enter into another male-dominated environment, you feel more confident, or your self-confidence gets stronger, and I think this is a good feeling for girls." Participant $\mathrm{K}$ formed a relation between the concepts of getting used to and negative cheering as, "You get used to bad words. It doesn't bother you anymore. It becomes a habit because for the people around us cursing is a way of normal, daily speech."

Participant V argued that the presence of women prevented negative cheering and said, "I heard this during the match, a fan was cursing and some people around him warned him about the presence of women. I think the people right around us tried to act better." Participant M emphasized that the presence of women on tribunes was an important factor in limiting the use of cursed words: "Actually we proved our existence. We made them accept our dominance in our tribune. They know we are there, so they act better. They understand that we can be involved in football, that we are here and that they need to get their act together. It did not end completely but it diminished." Participant G emphasized that the presence of a large number of women on tribunes increased awareness: "if you are one woman, nobody notices, but if you are ten, they notice." 


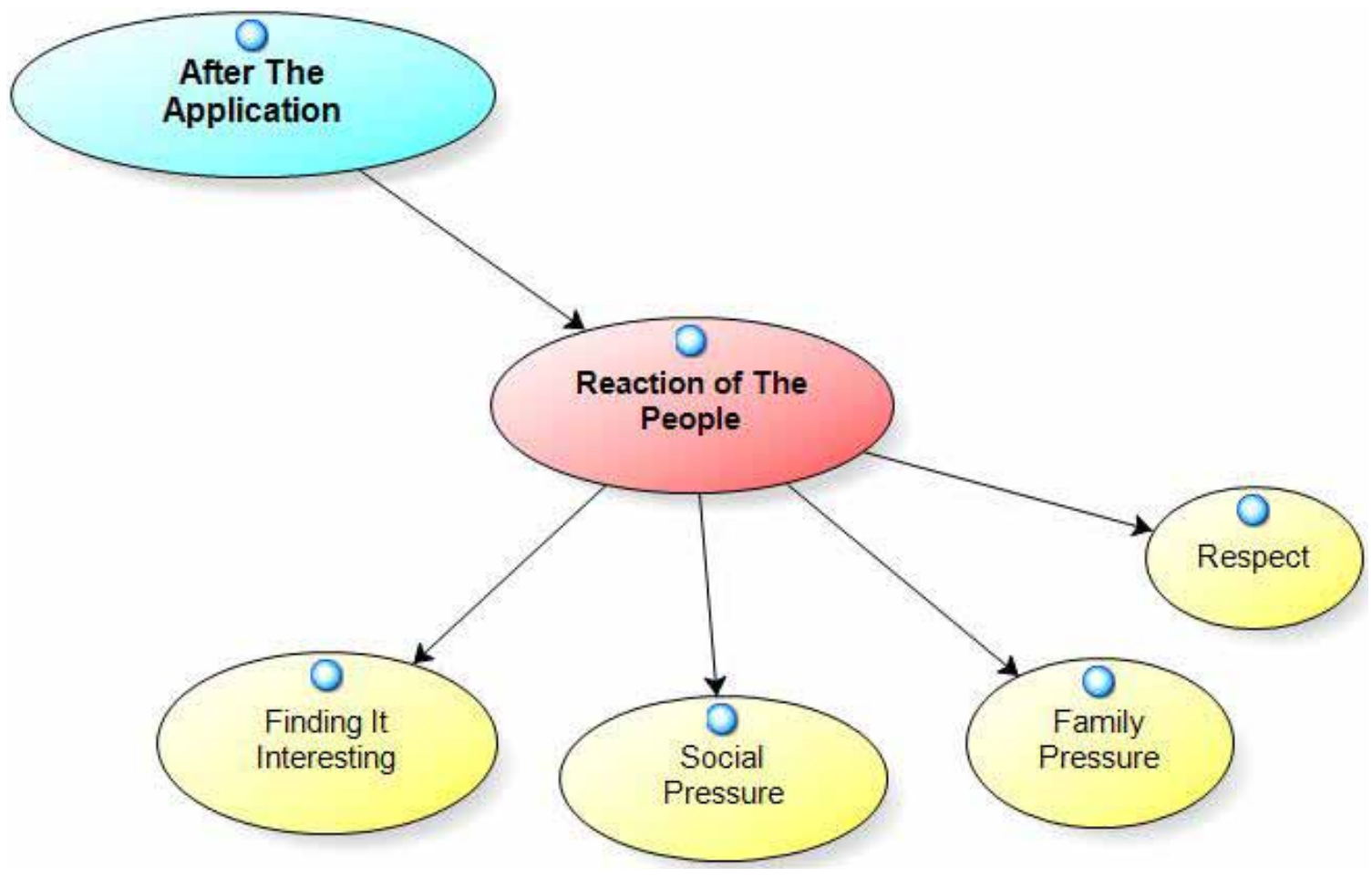

The findings obtained through the analysis of participant views after the application are resolved, and for "reaction of the people" theme, the concepts of "finding it interesting", "social pressure", "family pressure" and "respect" are revealed. Participant $\mathrm{K}$ and Participant $\mathrm{M}$ stated that their decision to go to the stadium received a negative reaction from the people in their environment in general, but they also emphasized that when those, who reacted, experienced stadium environment, their negative approach changed. Participant K said, "My roommate wanted to go to the stadium, too and we went together. She desired to go to matches, too. I was having fun, I mean when I went to the stadium, I came back happy, and she wanted to go to the stadium or see the environment too instead of staying at home, and began to come with us." Participant M said, "My father reacted at the beginning. When I was registering for Passolig, he found out and said he wouldn't give me money, but he knew me, and he knew that I would go. He doesn't cause trouble for now." When stating her friends' concern about going to the stadium, Participant V said, "My boyfriend criticized by saying what I would do there, among all those men, but then he got used to it. Because I have fun there, I am surrounded with fervor, I told him that and he understood. When he saw that I was happy, he stopped criticizing but he is still nervous. He still says things like what I am doing among all these cursing and men and hooligans."

About the reaction she received about going to matches, Participant B said, "My mother always says 'Don't go, you go everywhere and you sit in tribunes like men. Always among men, it is enough, I am tired of you, sit at home."” 


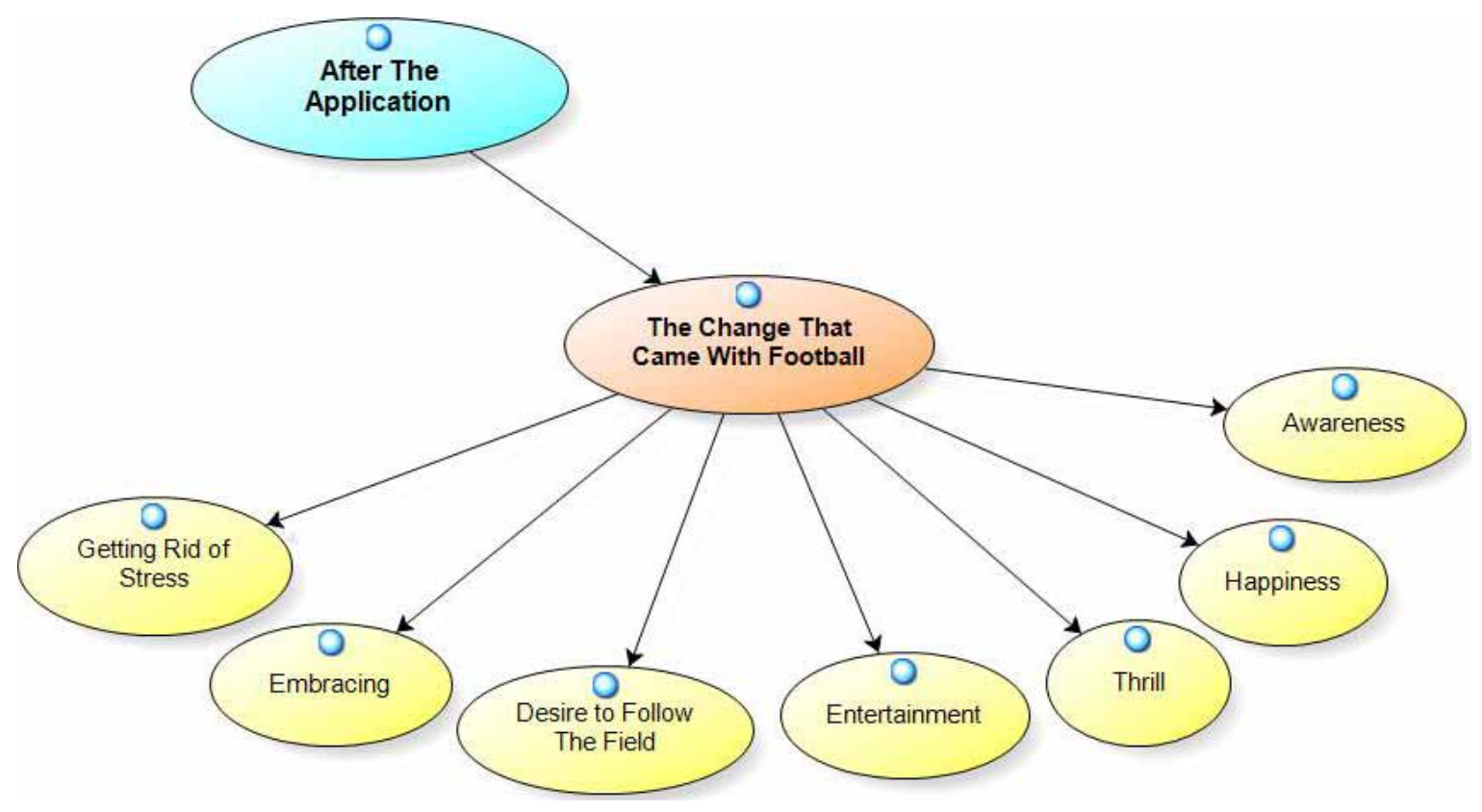

After the application, participants emphasized the positive influences of experiencing football matches. Their views are construed with the concepts of getting rid of stress, embracing, desiring to follow the field, entertainment, thrill, happiness and awareness. Following the application, Participant B stated her views as, "It made me feel very good. It is like you focus on a certain point with all of your energy during a match; you watch, stand up, get excited, feel sad when your team concedes a goal, you experience all the emotions. It makes you feel more energetic. I become more interested in not only Boluspor but also football."

Participant $\mathrm{K}$ and Participant $\mathrm{C}$ emphasized that the experience of going to matches had a positive influence on their communication with their friends. Participant K said, "It's increased my communication with my friends. I started to talk about Boluspor, and talk about missing opportunities and positions, etc. We started talking about the players and their performance at matches. After one match we wait for another. It is fun, so much fun." Participant C said, "We did not know each other at all. Sharing similar feelings brought us closer."

While explaining the comfort she felt on tribune, Participant C said, "I said to myself 'It's good that I'm here, good that I'm doing this' and it made me really happy to see more of us there. I always say it, that place is mine. That place is where I feel the most comfortable, which brings me tranquility. For 90 minutes I feel self-confident, I cheer and I relax."

Participant V explained how she began to understand the opposite sex better by means of football: "I began to understand that men are different. I also began to understand why they are different when they support a team. I used to think about curses, but here's the situation; you start to understand because you experience too much emotion in a very short time. You are sitting but in a second you see yourself on your feet when the player is going for goal, when the player misses it you get angry, you shout, may be you want to curse, but you cannot. Because we are girls, we try to keep calm, but I can understand them."

Participant D stated the positive change in her by saying "You get rid of the negative energy. I began to smile more." 


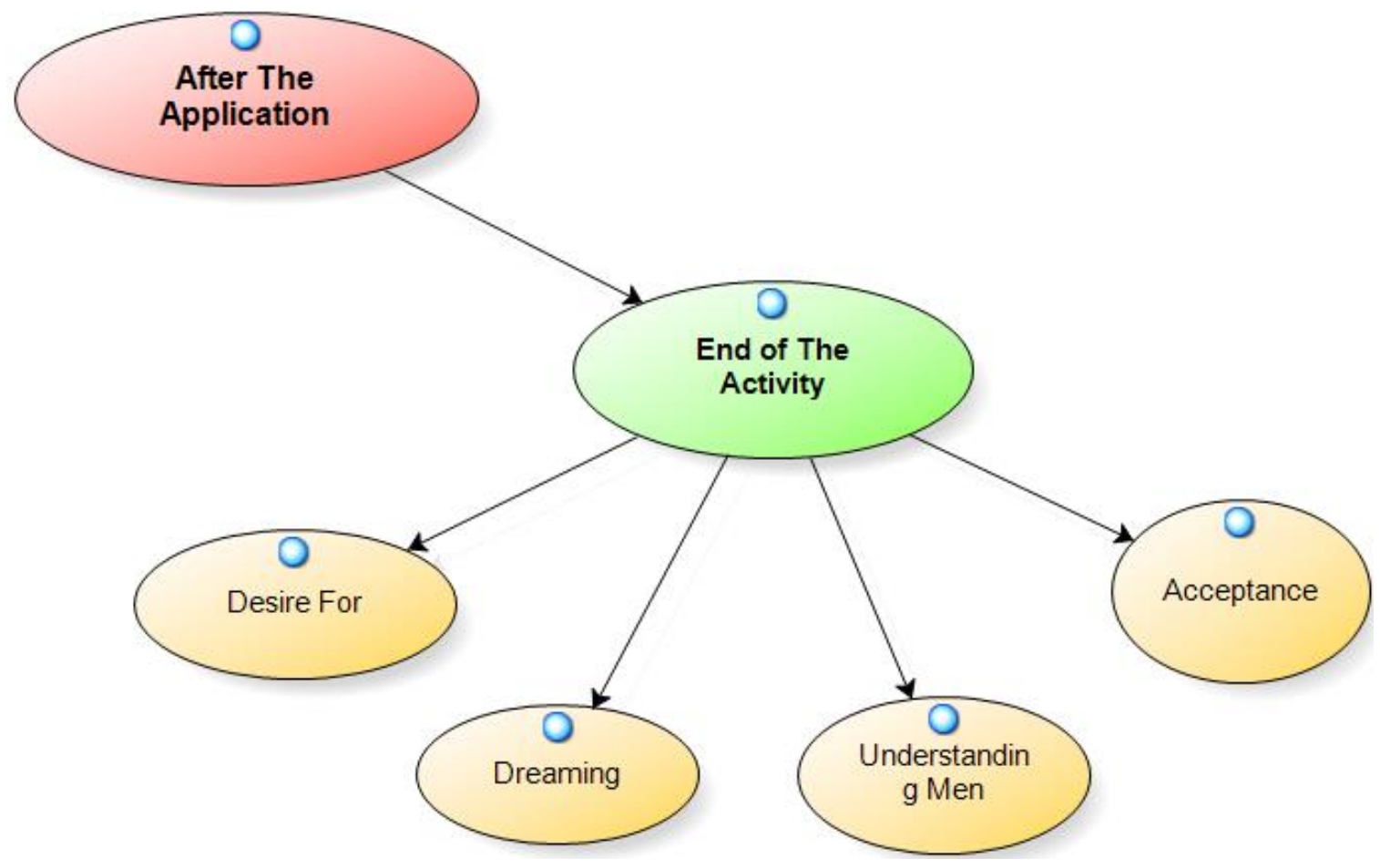

Participants expressed their views about the end of the activity after the application and these views are classified as acceptance, dreaming, understanding men and desire for continuity.

Participants told seeing matches on tribune created positive feelings after the application. Participant B said, "I wish it continued." Participant V stated that the application created a habit and said, "I will continue, even if there isn't a group, I will keep going myself."

Participant $\mathrm{K}$ explained how she developed a sense of favor for the team she followed during the application by saying "I used to go to matches thinking that I didn't favor Boluspor and didn't care if it won or lost. Then, however, we began to see it win, it had to win, we began to act in a peculiar way believing that our actions would help the team."

Participant $\mathrm{G}$ told the positive sides of seeing football matches and emphasized that it would have a positive influence on male-female relations. "I think it is great, I wish everyone could see such environment. Girls need to get rid of timidity they feel when they are around men. Then men start to see you."

Participant D was so positively influenced from the application that she wanted her child to become a football player: "I sometimes think, while I am seeing the matches, that I want my child to be a football player, and I want to sit on tribunes and watch him, I would feel so proud." 


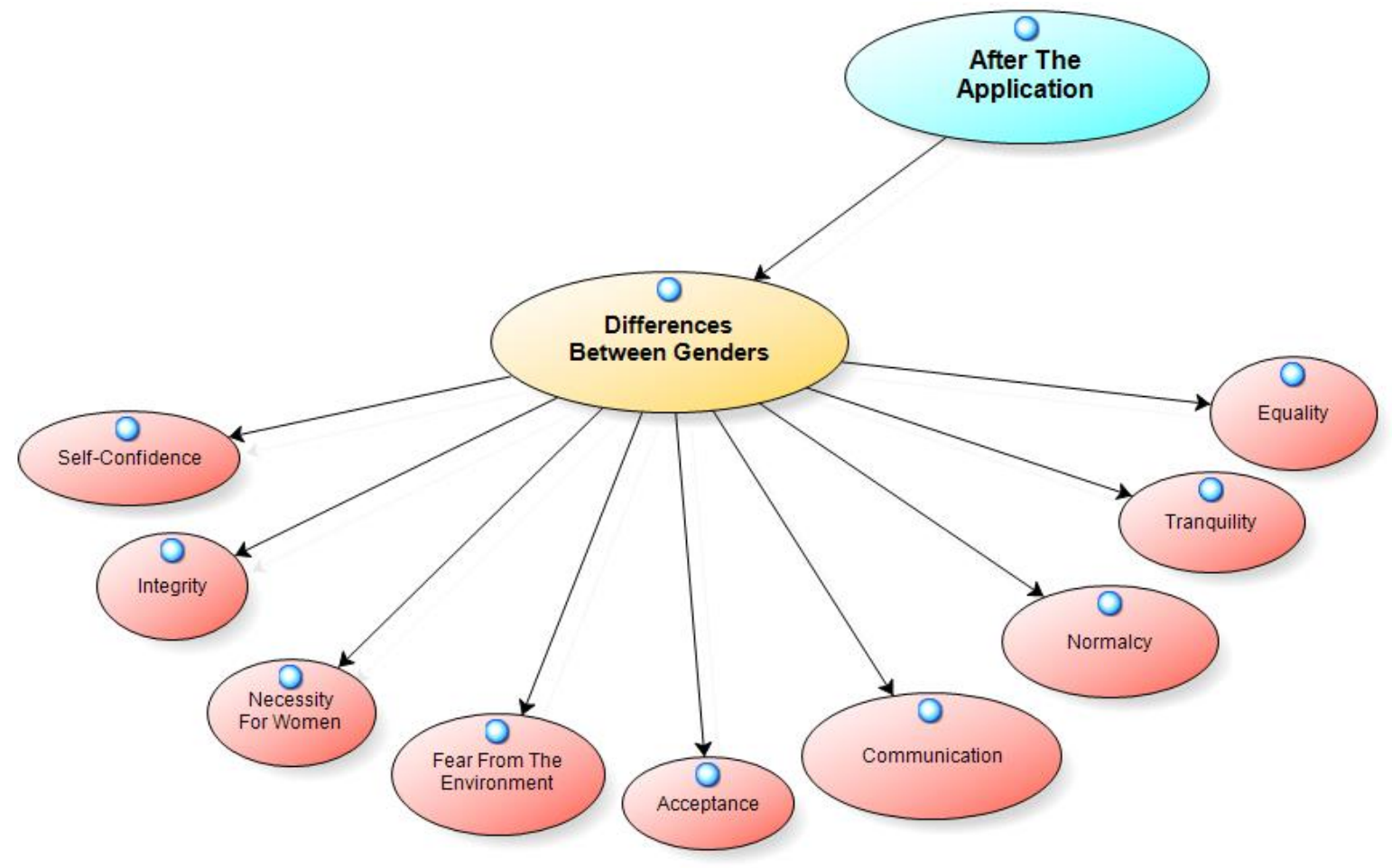

After the application, 9 aspects are determined for the differences between genders: normalcy, communication, equality, and fear from the environment, tranquility, necessity for women, acceptance, self-confidence, and integrity.

Participant $\mathrm{G}$ emphasized that gender did not play an important role in attending leisure time activities after the application with these words: "I think leisure time is personal. It doesn't matter if you are a man or woman. There is nothing preventing women form participating. As long as she wants she can attend anything."

Participant B explained that criticism played an important role for women in attending leisure time activities. "They generally think about other people's reactions. 'What would this neighbor say?' People don't want to enter such environments because they feel intimidated from such reactions."

Participant M drew attention to the factor of self-confidence in attending leisure time activities as a woman by saying, "Actually it is also about self-confidence. If someone has low self-confidence, one would not want to go to a stadium or anywhere else. It is not about being a man or woman. If one's communication abilities aren't strong, one won't be able to communicate with people; instead one would be intimidated and bored. Self-confidence may be important."

Participant K pointed out that one of the reasons why women did not take place on tribunes was that they did not prefer to be present: "I think it is completely about women, because men are ready to accept women, or men do not reject them. Since women withdraw themselves, men are seen as the ones who do not accept women. The same way we entered the sphere of football and have them get used to us, other women should do the same. It is difficult for one person to achieve that but it would be easier for a crowded group. Men get used to us and accept us when we act together."

Participant V put an emphasis on family and said, "It is the result of family upbringing."

Participant $C$ put forward cultural differences and said, "It can be related to the culture and region one grew up in."

Participant S and Participant D emphasized that a natural acceptance environment was formed when they went to see a football match. Participant S said, "One time I went with a friend and they began to talk to us directly. The following match they said 'aren't you the same girls?' and we had a conversation." Participant D: "A new environment is formed. They like you. When people wear the scarf of the same team, I feel like they wouldn't want to harm you. They act more friendly." 


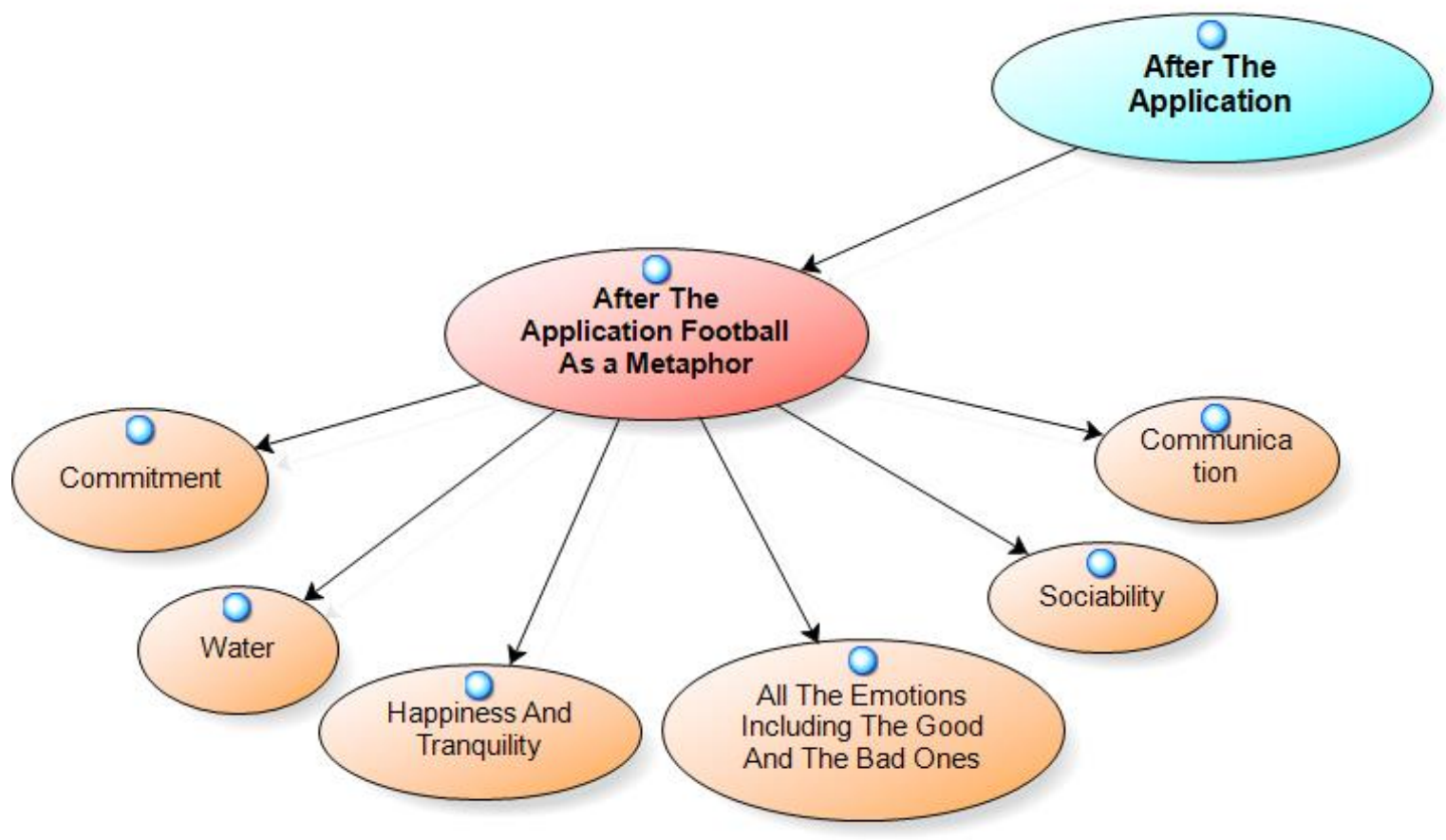

It is observed that participants' statements about their perceptions about football after the application are all positive: Thrill (Participant B), Water (Participant C), Commitment (Participant V), Sociability (Participant G), All the emotions including the good and bad ones (Participant K), Happiness and Tranquility (Participant M), Communication (Participant S).

\section{Discussion}

When the participant views are analyzed during the pre-application phase of the research, the themes of "leisure time", "thoughts about women and football", "prejudice", "sexism", "social and family pressure" and "violence" are revealed. It is also detected that these results are in parallel with the research in the literature.

Alexandris \& Carroll's study (2017), which examines the restrictions imposed on recreational sports participation in terms of gender in Greece, points out women are restricted more than men. In her study that evaluates women's problems in attending sports and leisure time activities, Güner (2015) reveals that women are prevented from attending recreational activities due to family structure, environmental and religious factors. Walseth and Fasting's study states that women always face problems about attending sports activities due to family pressure.

After the study, participant views focused on the themes of "happiness", "tranquility", "the necessity of getting rid of stress for women" and "sociability". These results are in parallel with the ones in the literature. Bulgu et al. (2015) finds that attending physical activity as a leisure time activity affects women's life styles positively and increases their life qualities in their research "Daily Life, Women and Physical Activity", which was conducted on 53 female participants. This result matches the conclusions obtained in this study. Sönmezoğlu's study (2014) emphasizes the outcome that, considering the gender aspect, leisure time satisfaction levels of women at "psychological", "educational" and "relaxation" sub-dimensions are higher than the level of men. While emphasizing that women's need for leisure time activities, especially intended for social interaction, is higher, Kabanoff (1982) determines that men's leisure time satisfaction level is stronger than women's level, and that attending leisure time activities affect women's life quality. Broughton \&Beggs (2006) emphasize that women have higher satisfaction points than men in physiological and relaxation sub-dimensions in their study conducted about individuals over 65 years old. Güner states that one other essential determinant for women in attending sports and leisure time activities is the perceived social support. It is observed that the research results in the literature also support Güner's argument, and it is determined that weakened social support has a negative influence on women's desire to attend sports and leisure time activities. Bulgu et al. concludes that participating in a physical activity in a social environment strengthens interaction among women and that this interaction prepares suitable conditions for them to realize their secondary state and actually talk about this situation; this conclusion is in parallel with the results of this study. Based on the interviews, it is concluded that women learn about each other and thus learn about themselves in private and public sports centers in Ankara, which become essential social environments for women to question their 
status. One of the reasons why Yllmaz \& Ulaş prefer recreational activities is that these activities give a chance to participants to feel happier and more tranquil. Senne (2016) stresses that woman still face gender equality conflicts in attending activities. His study also emphasizes that women should be relieved from their stereotypical gender roles, which requires social support for women to attend leisure time activities.

Based on participant views before the application, it is observed that they supported participating leisure time activities since most of them had background in sports field. As emphasized by Participant B, it is stated that more women should take place on tribunes. Before the application, family pressure was mentioned as one of the obstacles in front of women preventing them from going to football matches. Participant B stated one of the reasons that kept women out of football environment by saying "there is a concern about fighting. My family, too, puts a pressure on me saying I should sit at home."

After the application, Participant V mentioned his close circle had a concern about going to stadium, but then this concern disappeared. Participant $\mathrm{V}$ also stated that she wanted to go to stadium by herself if their group would dissolve. Participant $\mathrm{M}$ drew attention to self-confidence as an important factor for women in attending leisure time activities. Participant $\mathrm{K}$ emphasized that scarcity of women on tribunes was a result of their choice. This data shows that going to football matches may turn into a habit.

One of the results of this study is that presence of women on tribune is an important factor that limits the use of curse in cheering, an aspect emphasized by Participant M. Participant B emphasized that seeing football matches made her feel very good and more energetic.

The purpose of this study is to put forward the role of gender in attending leisure time activities and to determine gender perceptions about sports branches; the participants also emphasized that this separation was artificial. After the application, Participant G told gender did not play a role in attending leisure time activities, and it was a personal choice; "It doesn't matter if you are a man or woman. As long as a woman wants she can attend anything."

Based on the interviews with the participants, it is found that there were differences in attending leisure time activities and in perceiving sports branches in terms of gender; however it is emphasized that this could be overcome through time, education, acceptance, cultural development and environmental support.

The participants of this study involved in sports branches actively and this created a limited sample base; thus a similar study can be conducted with different groups following an analogous method. It is suggested to conduct a similar study with participants of different qualifications and demographic features.

\section{References}

Alexandris, K., \& Carroll, B. (1997). Demographic differences in the perception of constraints on recreational sport participation: results from a study in Greece, Leisure Studies, 16(2), 107-125. https://doi.org/10.1080/026143697375449

Amman, T. (2006). Woman and sport. İstanbul: Morpa.

Broughton, K., \& Beggs, B. A. (2006). Leisure satisfaction of older adults. Activities, Adaptation \& Aging, 31(1), 1-18. https://doi.org/10.1300/J016v31n01_01

Bulgu, N., Koca, A. C., \& Aşçı, H. (2007). Daily life, women and physical activity. Hacettepe J. of Sport Sciences, 18(4), 167-181.

Çokluk, Ö., Yılmaz, K., \& Oğuz, E. (2011). A qualitative interview method: focus group interview. The Journal of Theoretical Educational Science (JTES), 4(1), 95-107.

Demirci, O. F., \& Yavuz, M. C. (2003). A pilot study on determining customer potential in recreational tourism. Çukurova University Journal of Social Sciences, 11(11), 61-76.

Güner, B. (2015). The evaluation of the problems related to the women's not being able to participate in recreation activities. Journal of International Sport Sciences, 1(1), 22-29.

Kabanoff, B. (1982). Occupational and sex differences in leisure needs and leisure satisfaction. Journal of Occupational Behaviour, 3, 233-245. https://doi.org/10.1002/job.4030030304

Karaküçük, S. (1999). Recreation: Assessing leisure time. 4th Edition, Ankara, Gazi.

Koshar, R. (2002). Histories of leisure. New York: Berg Publisher.

Merriam, S. B. (2015). Qualitative Research A Guide for Design and Implementation in Turan S. (Eds.). (pp.83-131). Ankara. Nobel.

Miles, M. B., \& Huberman, A. M. (1994). Qualitative data analysis (2nd ed.). Thousand Oaks, CA: Sage Publications. 
Munusturlar, M. (2016). Recreation management. Anadolu University Publish, No:3414. Eskişehir.

Özbey, S., \& Çelebi, M. (2011). Principle of recreation.In Mirzeoğlu N. (Eds.) Introduction to sports sciences (pp. 247-260).Ankara: Spor Yayınevi.

Özsoy, S. (2016).Viewpoint of journalist candidates on sports media as part of gender in Turkey. Journal of Communication Faculty of Akdeniz University, 26, 85-103.

Rojek, C. (2005). Leisure theory principles and practice. First Published. Palgrave London. Macmillan.

Senne, J. A. (2016). Examination of gender equity and female participation in sport. The Sport Journal, 19, 1-9.

Sönmezoğlu, U., Polat, E., \& Aycan, A. (2014). Youth center members and according to some variables levels of leisure satisfaction. International Journal of Science Culture and Sport (Special Issue 1). https://doi.org/10.14486/IJSCS91

Walseth, K., \&Fasting, K. (2004). Sport as a means of integrating minority women. Sport in Society, 7(1), 109-129. https://doi.org/10.1080/1461098042000220218

Yıldırım, A., \& Şimşek, H. (2008). Qualitative research methods in the social sciences, (7th ed.). Ankara: Seçkin.

Yılmaz, A., \& Ulaş, M. (2016). Making goals physical activity of women and challenges faced in recreactional areas. Hacettepe J. of Sport Sciences, 27(3), 101-117.

Zorba, E. (2007). Perspective and development of recreation in Turkey. Gazi News Magazine, September, 52-55.

\section{Copyrights}

Copyright for this article is retained by the author(s), with first publication rights granted to the journal.

This is an open-access article distributed under the terms and conditions of the Creative Commons Attribution license which permits unrestricted use, distribution, and reproduction in any medium, provided the original work is properly cited. 